Trinity University

Digital Commons @ Trinity

Modern Languages and Literatures Faculty

Research

Modern Languages and Literatures Department

2007

\title{
The Dangerous Quest for Nature Narratives in Goethe's Werther. A Reading of the Ruptured Monologue and the Ruptured Body
}

Heather I. Sullivan

Trinity University, hsulliva@trinity.edu

Follow this and additional works at: https://digitalcommons.trinity.edu/mll_faculty

Part of the Modern Languages Commons, and the Modern Literature Commons

\section{Repository Citation}

Sullivan, H.I. (2007). The dangerous quest for nature narratives in Goethe's Werther: A reading of the ruptured monologue and the ruptured body. Interdisciplinary Studies in Literature and the Environment, 14(2), 1-23. doi:10.1093/isle/14.2.1

This Post-Print is brought to you for free and open access by the Modern Languages and Literatures Department at Digital Commons @ Trinity. It has been accepted for inclusion in Modern Languages and Literatures Faculty Research by an authorized administrator of Digital Commons @ Trinity. For more information, please contact jcostanz@trinity.edu. 


\section{The Dangerous Quest for Nature Narratives in Goethe's Werther: A Reading of the Ruptured Monologue and the Ruptured Body}

Goethe's best-selling 1774 Sorrows of Young Werther swept the world with Werther-mania driven by its sad love story, intense script of modern subjectivity, and, most significantly for this essay, the rather ecocritical deliberation of how to write narratives of nature. In this epistolary novel, nature appears either as a utopian pastoral dream or as an "eternally consuming and regurgitating monster." Werther experiences the first of these two extremes in the solitary enjoyment of his valley sanctuary and when overwhelmed by ecstatic, panoramic love after meeting the young, beautiful but engaged Lotte. He later embraces the second, dark vision of nature's consuming forces when Lotte's bourgeois fiancé Albert returns. These two emotional landscapes appear to be opposites, yet Werther's words in each case actually describe the flip sides of the same problematic image. He zealously pursues immersion in a vision of nature that reveals itself as a trap of dualistic thinking, and that leaves him on a futile quest to (re-)unite himself with world/mother/Lotte/children/bugs and all of nature as represented by the ubiquitous water imagery in the novel. Unable to sustain the joy from the famous May $10^{\text {th }}$ letter describing his pastoral lolling by the stream where he can feel his heart's nearness to the teeming bugs, Werther finally ends up on a cliff considering "storming down" into the "abyss" and becoming one with the flooded river--his final great hope for complete immersion!--yet he rejects this idea and instead goes home to use Albert's pistol. The novel's conclusion, with this turn away from the delirious urge to sink into nature's "flux" as if it were a separate outside force, and the brutal rupture of Werther's body with a shot to the head, presents a Goethean moment of insight where the protagonist's deluded visions of immersion meet their demise. This bodily rupture parallels the textual rupture occurring when the editor ends Werther's epistolary monologue with his own and other voices. In emphasizing these two ruptures, I read Werther's 
suicide not just as the reaction to frustrated love and confused social ambition, or as the breakdown of the modern, middle-class subject with creative impulses, but rather as the annihilation of the narrative form that claims unmediated immersion into "nature." [1] Werther's dangerous quest thus ends violently with the ruptures of monologue and body, yet the space thereby opened up offers an alternative possibility for nature texts.

In assessing these ruptures, this essay follows their trail in three directions: first through the editor's sudden interruption of Werther producing the post-epistolary multiplicity of voices (including parallel leaps into lengthy passages from other authors: Ossian at the end of part One, and Johann Christian Kestner's letter about Jerusalem's suicide at the end of part Two), second in the alterations Goethe made to the 1787 revision of Werther that enhance the theme of rupture itself, and third along the fault-lines delineated in three exemplary "letters of nature" from Werther (10 May, 18 August, and 8/12 December).[2] I begin with the structural questions so that Werther's siren cries of nature shall not lure us into their dangerous delirium before we can steady ourselves with the analysis of narrative devices. Laugh if you will at such caution, yet remember that not only did this novel provide a highly lauded model for Romanticism's revelry in nature, it also became a world-wide literary phenomenon that inspired many young men to dress like Werther and some even to join him in suicide.[3] Prudence here is particularly relevant in light of ecocriticism's celebratory emphasis on nature writing. Werther, the famed writer of nature/self, still seduces readers with his tale: but is it sympathy's sway or ironic play--or both?

Let me thus first note that The Sorrows of Young Werther is an epistolary novel in part. One must emphasize in part as Werther's monologue of letters, with its lyrical celebration of soft nature at the stream merging into images of the soft, virginal, yet motherly Lotte and its later harsh images of the all-consuming, gaping abyss, notoriously often deceives the reader into forgetting the violent shift in narrative form that provides the text with its power and its 
alternative vision. After only the briefest introduction from the editor, Werther's world as presented in his letters fills the pages with no responses for $3 / 4$ of the text, that is, until the editor's voice abruptly reappears, interrupting the soliloquy. The editor speaks directly to the reader: "I wish that we had so many documents by his own hand about our friend's memorable last days that I did not need to interrupt the sequence of his letters by a connecting narrative"; $[4]$ and then he continues the story from a mixture of views including the apparently omniscient voice and the first- and third-person thoughts of both Werther and the other figures. There is obviously a functional question of describing Werther's death and funeral that he cannot himself write, but the timing of this editorial move occurring long before the actual suicide calls out for attention. The critical responses to this cry follow three general strategies: first, to sympathize with Werther, to feel Goethe's partially autobiographical pain and uncritically revel in his suffering to the extent that the editor appears just a continuation of the story; second, to emphasize the critique implicit in the arrival of the editor, to see the text as ironic, as a means to overcome such indulgences; and, third, to recognize that the novel itself is not merely one or the other (much like the vision of nature), but rather a juxtaposition of both--it is the third approach of juxtaposition that this essay follows.[5] Thus I read the rather graphic depiction of Werther's final twelve hours of bloody death rattles together with the abrupt move from singular, epistolary subjectivity into multiple voices and multiple views as a decisive move away from dualities such as simple celebration or critique (of nature or of Werther himself) and towards juxtaposition (of views, of mediated or unmediated nature representation, of narrative styles) as an end in itself.

The epistolary function of Werther simultaneously performs and questions through its production of letters the challenges of "writing nature" (a quest engaging the debates of "realism," "mimesis," "representation," “construction," and "mediation"). This quest for nature (re-)presentation appears directly in Werther's lively portraits of luscious/treacherous landscapes, 
and then self-consciously in his own comments about how difficult it is to create such emotional portraits.[6] In the famous second letter from May 10, for example, he hopelessly longs to "breathe onto paper all that lives so full and warm within me" as he lies in the "tall grass by the trickling stream," yet the very act of bemoaning his inability to capture all of this moment on paper occurs in a letter (6). It is, thus indeed, on paper, and it participates in the open deliberation of the very possibility of unmediated perception and textual depiction. Werther simultaneously denies his ability to paint nature even while successfully painting with words an "immersion into nature," one so splendorous that he claims it will "destroy" him: "O my friend - but it will destroy me-I shall perish under the splendor of these visions" (6). He repeatedly complains about his inability to put into narrative his experiences, even while he creates letters that at least in part do just that.

I contend, however, that while Werther the figure finally fails to come terms with the problems of representation, Werther the novel at least creates a space of energetic, if unresolved, juxtapositions. The text achieves this dramatically in its violent shift in narrative form, in its move from epistolary style--in the monolithic Wertherian perspective dictated in letters with no answers--to a mixed narrative with multiple perspectives.[7] Werther is already radical in its unusual epistolary form that presents only one voice, thus eliminating the dialogue and conversation more typical of the form; yet Goethe thereby all the more provocatively exploits the editor and his access to multiple voices and insights at the end of the story. An editor in an epistolary novel is commonplace, yet this version's edginess should not be overlooked: first, as noted, the dominant monologue contrasts strongly with the final multiplicity of voices, but also the editor's voice itself evokes uncertain origins leaving the critics arguing whether he's the ghost of Werther, Goethe himself, Wilhelm (to whom the letters are addressed), or an imperfect, omniscient/mixed voice.[8] This uncertainty in combination with the stark textual rupture 
destabilizes, I suggest in contrast to one common interpretation of Werther, all possibility of blithely reading the novel as supreme sentimentality celebrating the woes of the outsider, artist, or modern subject. Indeed, the association of this novel with romanticism's lyrical dissolution of "self" in poetic free play (interpretations which typically either ignore the editor altogether, see him as merely an extension of Werther himself, or else understand the switch simply as a reasonable manner of depicting his death) entirely misses the point of a text marked by a jarring hinge, an unsettling juxtaposition of narrative views and form. [9]

At the moment of the rupture when the editor's voice reappears, we leave behind Werther's inward speculations and hear comments on Werther's behavior in a mixture of styles: the "omniscient" voice describing what he does and thinks; the occasional switch back to notes and other additional first-person words from Werther; thoughts from Lotte on the last few days before and after his death ("Charlotte was sitting alone. None of her family were near and her thoughts turned to her own situation: she was married to the man whose love and fidelity she trusted, to whom she was deeply devoted [... On the other hand, she had grown so fond of Werther [etc., etc.] (75)); information about his demise from other characters including Albert and the servants; and, significantly, another author's voice entirely in the long, pages long, citation (one often asks: why so long?!) from MacPherson's Ossian.[10] The extensive, tortured passages are read out loud breathlessly by Werther and Lotte until they finally fall into a real embrace and kiss--the ultimate breaking point as Lotte pulls away and cries that he is never to see her again. They finish reading together, sobbing together, until:

The whole force of these words fell upon the unfortunate Werther. [ . . Charlotte's] thoughts were confused: she held his hands, pressed them to her bosom; and, turning toward him with the tenderest expression, her burning cheek touched his. The world vanished about them. He clasped her in his arms tightly, and covered her trembling, 
stammering lips with furious kisses. 'Werther!' she cried with choking voice, turning away. 'Werther!' and, with a feeble hand, pushed him from her. [ . . . Charlotte rose, and with confusion and grief, trembling between love and anger, she exclaimed, 'This is the last time, Werther! You shall never see me again!' (81).

If nothing else, this novel is about the power of literature, about love and death inspired by fiction. Yet besides such literary issues, including also Werther's switching allegiance from the Odyssey (which he reads, as according to Goethe's famous later statement, when he's still relatively sane) to Ossian, this section once again asserts the juxtaposition itself, the move into voices that are not all just Werther's. The novel begins with the editor, is filled in the main part with Werther's vision and his nature writing, and ends with multiple voices on three levels: first, the various figures "within" the story personally experiencing Werther's demise, second, the editor's view from "outside" summarizing his findings, and third, large sections of a completely unrelated text from an entirely different author--one which itself is a series of different voices from different singers.[11] Even this final step outwards is not simply a pure, new voice (as Werther's voice itself is not); it is instead Werther's (Goethe's) translation of a translation. With each of these steps, Goethe extends the rupture and complicates the question of authentic voice and immediacy until his novel reaches literally outside of itself into another text. It is not insignificant that this other text from Ossian is itself supposedly a collection of translated folk songs, thus a collection of multiple voices and sources (but actually, unbeknownst to Goethe yet equally appropriate, it is a modern recreation).[12]

Many interpretations of the extended Ossian scene focus, in contrast, on the biographical interest of Goethe or on the obsessive literary love that drives Werther from the Odyssey to the emotional storms of Klopstock's poetry to Ossian to Lessing's great bourgeois tragedy, Emilia Galotti, that is left open on Werther's desk at the time of his suicide.[13] I see these literary 
inclusions and extended citations as an indication that Goethe is taking the polyphonic, multilevel narrative shifts and ruptures to their farthest possible point of extra-textual reference and "inauthentic" voices. While the juxtaposition of voices and texts in the rupture pretends continuity, we should remember that it also reveals the jagged edge of the juxtaposition itself. This jagged edge that reaches out to extreme extra-textual references also provides a model for nature texts: it creates a space of "mediated immediacy," to quote Edgar Landgraf, a space where nature and text might interact without the fiction of simple unmediated connection nor the pretend reserve of desired objectivity.[14] We are pulled with Werther into the immediacy of emotions and then the rupture breaks us out; yet the jagged edge itself allows the multiple voices to enter, which then, in turn, re-engages us at other levels. This is a space at the hinge, a back and forth that is both mediated and unmediated and finally neither one exactly. It's the constant motion of shifting, Goethean, polarity that is truly galvanized only in the rupture.[15]

The effect of this jagged edge in Werther occurring at the moment of editorial rupture is exaggerated in the changes Goethe made to the famous 1787 revision--which is the one most available in English translation. This essay shall focus on several specific differences between the two versions (many scholars view the 1787 text simply as a refinement and a slight shift away from Werther's perspective, altered in order to discourage any further readers from following the fashionable trend of dressing like Werther, reveling in the sorrows of life, and then shooting themselves).[16] There are two noteworthy variations between these versions that I shall address here: first, the expanded comments of the editor at the moment of rupture in the later version, and, second, the fact that the rupture occurs at an earlier point in the second version. I suggest that these changes draw greater attention to Goethe's concern with the juxtaposition of narrative form; and also that it is in this shift where we find the most intriguing implications for the writer's quest to capture unmediated nature on paper. 
The original 1774 version has the editor simply claim that "he sees himself forced to interrupt the letters with narrative," for which, he "has gathered materials from the mouths of Lotte, Albert, his servants, and other witnesses."[17] The 1787 version, in contrast, is expansive: I wish that we had so many documents by his own hand about our friend's memorable last days that I did not need to interrupt the sequence of his letters by a connecting narrative. // I have felt it my duty to collect accurate information from persons well acquainted with his history. The story is simple; and all accounts agree, except for some unimportant particulars. Only with respect to the character of the persons involved do opinions and judgments vary" (65).

The single sentence from 1774 is replaced by three paragraphs, the first two of which are above. This juncture is now expanded, its role elaborated, the need regretted, yet the veracity emphasized. The original brief reference to the specific names of the other figures (Lotte, Albert, etc.) is dropped in favor of more emphasis on the editor's central role, details regarding the quality of the information, the general agreement, and the slight divergence in views on the emotional states of the "actors." The reader is more elaborately told that the text is now switching formats and voices here; Goethe thereby makes emphatic the rupture. Thus the third new paragraph from 1787 has the editor present his hard, "conscientious" work in obtaining and presenting all the evidence: "All that is left to do, then, is to relate conscientiously the facts which our persistent labor has enabled us to collect, to give the letters found after his death, and to pay attention to even the slightest fragment from his pen, especially since it is so difficult to discover the true and innermost motives of men who are not of the common run" (65). While many interpretations emphasize the editor's goal of understanding Werther as an "unusual man," I would suggest again that the editor is also drawing attention to himself and his role here in mediating the story, in piecing together the fragments, in relaying the words from the mouths of 
various other personages. We do find subjectivity here, but not only the so excessively celebrated inward-turning monomaniacal swing into suicide that made this novel a best seller and a worldwide phenomenon; instead it is the subjectivity of a narrative as openly "put together" from remnants and other voices, but also a subjectivity juxtaposed with claims of objectivity derived from hard research and careful labor. The expanded comments of the editor about his own role bring to light what I see as absolutely central to understanding The Sorrows of Young Werther, even already in the first 1774 version. The text is able, through the rupture, to be both subjective and objective, mediated and unmediated; that is, it creates a venue, perhaps brief, where the dualism translates into an active polarity that rejects the dangerous allure of final positioning on either side. This is the Goethean shift, the dramatization of the juxtaposition itself.

The timing of this editorial shift has all the more meaning in that it, too, varies between the two versions. The editor reappears and "breaks the flow," as it were, of the 1774 version right after Werther's December 17 letter describing what one could call a "wet dream" about Lotte. Note the protests about his brotherly love in contrast to his vivid description of embracing and kissing her in the dream as if driven by "alien powers," a dream ending with the water imagery of "swimming, and drunkenness" and the "bliss of ardent joys":

What is this, my friend? I shrink from myself! Is not my love for her the holiest, purest, most brotherly love? Have I ever felt a culpable desire in my soul--I will make no protestations--And now, dreams! O how true was the feeling of men who ascribed such contrary effects to alien powers! Last night! I tremble to say it, but I held her in my arms, firmly pressed to the breast, and covered her mouth, which murmured love, with unending kisses; my eyes were afloat [schwamm, "swam" in German] in the intoxication [Trunkenheit, "drunkedness" in German] of hers! God! am I culpable, that even now I feel a bliss in recalling those ardent joys in all their intensity? Lotte! Lotte![18] 
Werther is overcome here, and although this is not the first dream of Lotte he reports (the first one occurs in the August 21 $1^{\text {st }}$ letter, just after Albert has returned), it has the greatest intensity. The earlier and shorter dream finds Werther kissing only Lotte's hand, whereas this more emphatic December 17th letter has kisses on the mouth and includes questions of "culpability" and then the "bliss of ardent joy." The "wet" aspects of the later dream also appear all the more elaborate in the extended metaphors of water imagery. This is the final letter in the 1774 text before the editor intervenes, a letter of a dream, a letter of sexual desire, a letter powerful enough that it demands intervention.

This powerful letter exists in both versions of Werther, yet it is pushed back to a time quite a while after the editor interrupts in the 1787 text. The rupture in the 1787 version, then, occurs at an earlier point in the novel, and it is again follows reference to a dream. Yet it is quite a different type of dream that brings in the editor this time. It is now the (newly labeled as such) December $6^{\text {th }}$ letter in which Werther ponders the "demigod" status of man who closes his eyes and dreams of infinity:

How her image haunts me! Waking or asleep, she fills all my thoughts! When I close my eyes, here, in my brain, where all the energies of inward vision are concentrated, are her black eyes. Here--I can't express it. But if I shut my eyes, there are hers: dark as the ocean, as an abyss they lie before me, and fill the nerves of my brain. // What is man--that much praised demigod? Do not his powers fail when he most requires their use? And whether he soar in joy or sink in sorrow, is he not inevitably arrested? And while he fondly dreams that he is grasping at infinity, is he not at that moment made doubly aware of the dull monotony of his existence? (65).

Note, again, the water imagery, but here as an abyss within, perceived as he closes his eyes and sees there Lotte's eyes. The dreams of inwardness and images are emphasized here over the more 
physical desire of the December $17^{\text {th }}$ letter. Both moments of editorial interruption thus occur after radically different dream references.

If the particular moment of textual rupture indicates the point when Werther is no longer coherent enough to produce clearly dated and sequential letters, when his emotional status has decayed to a level of such low functioning that he either stops sending letters or else the editor no longer allows him to speak directly, then Goethe is shifting this point to an earlier moment in his revision. The alternative timing of the rupture is moved from following the "wet" dream about Lotte to the dreams about "grasping at infinity," thus it moves from a more personal and sexually suggestive letter to a more abstract grappling with the inwardly-turning perception of "man's status" in this world. Furthermore, the wet dream's position in the original version could lead the reader to see the editor's interruption more as an avoidance of textual impropriety than the inevitable collapse of an emotional young man wondering whether he is a demigod. Goethe claims these 1787 alterations were made with the consideration of the reader's safety (so powerful this text!), with the result that Werther's concerns appear more ephemeral and idealistic. Goethe's stated intention of making Albert seem less antagonistic towards Werther in the later edition is part of this increased emphasis on Werther's own, "subjective" impressions as the cause of his downfall rather than his collision with a hostile world. Yet the move in narrative position finally also serves to emphasize the significant role of the text's rupture itself, whether its placement occurs in the wake of overflowing sexual desire or in the moment of turning inward where Werther sees before him, in him, the gaping abyss of Lotte's eyes.

The 1787 alterations also relegate several significant letters to the "post-rupture" mode of instability and editorial intervention: besides the wet dream, there is also the lengthy depiction of a night storm with the flooded river where Werther considers letting himself fall into the watery abyss. This letter moves us from analysis of structural ruptures in the monologue and Goethe's 
revisions, and into analysis of nature and the physical ruptures of the body. In order to understand the relevance of Goethe's repositioning of the flood letter (from December $8^{\text {th }}$, just before the wet dream/rupture, to December $12^{\text {th }}$, within the mix of voices and editorial comments), one must see it in context, as the third in a series of dangerously seductive nature letters leading towards Werther's final crescendo.[19] The first two of these "nature" letters exhibit minor differences in the two versions; it is only the third that moves sequentially. I finally turn to these three letters with the hope that we are now insulated enough by the structural issue of ruptures so that we shall not, as so many have done before us, find ourselves blindly swept along with Werther's ecstatically emotional journey into "nature."

These exemplary nature letters delineate Werther's stages of development in response to specific events (solitude and Lotte; Albert's return; the marriage). While they thereby portray his internal landscape and reveal his own shift from nature revelry to nature horror, they are most significant in their virtually identical quality that varies only in the emotional timbre. This, I believe, demonstrates the sameness, the dualism of a vision of nature that is either beautiful and harmoniously humming with life or else dark and horrifically indifferent to the endless cycles of natural devastation, storms, and the inevitability of death. Both views, and all three of these nature letters, are drawn with the same spiritual vocabulary of bliss [Wonne], the same use of water imagery and metaphors, the same passive positioning of self in reaction to active

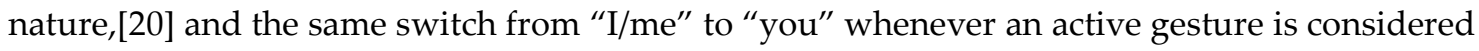
(although the translators mostly neglect this switch). The Sorrows of Young Werther thus draws an illusionary rupture in its rendering of nature, a shift from revelry to horror, yet this false rupture actually reveals itself as a continuity in contrast to the real rupture of narrative form and the destruction of naïve immersion. 
We turn then to the first letter, the (particularly seductive) pastoral found in the famous May $10^{\text {th }}$ exaltation. It finds Werther reveling at the side of the stream just after having arrived in his "inner sanctuary" that is nature. He describes: "the lovely valley" which "teems with mist around me, and the high sun strikes the impenetrable foliage of my trees." He is lying in the grass and sinking down alongside "the worms and insects," until he feels "the presence of the Almighty Who created us," whose "universal love" "sustains us as we float in an eternity of bliss [Wonne]," and then "the world grows dim before my eyes and the earth and sky seem to dwell in my soul and absorb its power" (6). This is the pastoral writing of nature that unites the protagonist/reader to the landscape's glorious minutiae and thereby connects him/us to the heavenly creator. This is the sentimentality raging through late Enlightenment, pre-revolution, post-Rousseauian Europe, and this is what the vast majority of the Werther reception sees as definitive. This is also the magic sought by so many contemporary nature writers who want to inflame their readers with nature's beauty and thereby initiate greater environmental enthusiasm. This passage fulfills it all and it's typically representative of Werther: there's the bliss, the placement next to the stream that is supplemented with watery metaphors, the fact that Werther's position is prone and overcome (passive) and, just at the moment of glory, when Werther wishes to capture the warmness of his soul rising from this vision, he switches from " $\mathrm{I}$ " to "you": "then I am often all longing and I think: ah, could you express all that again, could you breathe onto paper that which lives in you so fully, so warmly, so that it would become a reflection of your soul [...]."[21] Werther is passive and his wish for active production-mediation of nature onto paper--is itself mediated through the consistent switch to speaking to himself as "you." Werther here creates his own polarity, one of self as I/you, just as he considers the move out of his fictional passivity and into an equally fictional activity. It is itself a small-scale 
rupture, right at the moment of (desired) fusion with nature. Significantly, this switch and the passivity mark all of Werther's nature letters.

The second nature letter from August 18 contains the transition of Werther's views of nature. It marks the moment after Albert returns and is itself a juxtaposition: Werther first describes his joy in nature, but in the past tense, and then he shifts within the same letter to the description of the horrible, fatal forces of the universe. Despite the famous turn to seeing nature as "an all-consuming, devouring monster," this letter, too, has bliss, relentless water imagery, Werther as passive, and the switch from "I" to "you." "Misery," he cries: "The rich and ardent feeling which filled my heart with a love of Nature, overwhelmed me with a torrent of delight [Wonne-bliss], and brought all paradise before me, has now become an insupportable torment--a demon which perpetually pursues me" (36). Water, Wonne, and poor passive Werther. The river, the clouds, the humming beetles, it "all conveyed to me the holy fire which animates all Nature, and filled and glowed within my heart. I felt myself exalted by this overflowing fullness, as if a god myself, and the glorious forms of an infinite universe stirred within my soul! Stupendous mountains encompassed me, abysses yawned at my feet [ . . etc. etc.]" (36); Werther felt (but no more) overwhelmed, overflowed, washed away by nature's power--and that was the good part. He now longs once again "to drink the pleasures of life [Lebenswonne] from the foaming goblet of the Infinite," yet his recollections only lead him to "feel doubly the intensity of my present anguish" (36). In the second part of the letter we find the negative vision, one dominated by the image of the abyss and the flood, thus the metaphorical vision that is later translated rather precisely into the literal flood and abyss into which Werther considers letting himself fall (in the third nature letter). Here in the transition letter, Werther is obsessed with the idea of nature's destructive powers. The humming bugs are still here, but subsumed by the torrent where time rushes by with the "speed of a storm" carrying all things onward in the face of "our transitory 
existence," where all "is swallowed up by the waves or dashed against the rocks" (37). Here is another I/you switch (there are three in this letter): “It is as if a curtain had been drawn from before $m y$ eyes, and, instead of prospects of eternal life, the abyss of an ever-open grave yawned before me." [...] There is not a moment that doesn't consume you and yours--not a moment in which you don't yourself destroy something. The most innocent walk costs thousands of poor insects their lives; one step destroys the delicate structures of the ant and turns a little world into chaos" (37, emphasis mine). Werther thus notes in this letter that "you are a fool" and "you perceive everything to be so small, because you are so small"; he asks if you can say "that's how it is!"; and he wails that your every step destroys a miniature world.[22] This threefold I/you switch solidifies his passive stance to nature whose active powers now take on the famously horrifying image: "My heart is wasted by the thought of that destructive power which lies latent in every part of universal Nature. Nature has formed nothing that does not destroy itself, and everything near it. And so, surrounded by earth and air and all the active forces, I stagger on in sheer anxiety. The universe to me is an all-consuming, devouring monster" (37). This transition letter thus continues Werther's "I/you" switch, his passive stance, use of water imagery, and references to bliss, "Wonne." It's not just societal restraints imprisoning him; it's his own dualistic vision that perceives nature as radically beneficent or horribly consuming, but always from the same positioning of self.

Nature's most aggressive and negative reality and the embodiment of Werther's most anguished cries about consuming forces find their truth in the third letter I consider here, the $8^{\text {th }} / 12^{\text {th }}$ December letter describing the night flood. Yet in the 1787 version, they go from being a final "actuality" to just one more moment of post-rupture ranting as found in fragmented letters, notes, and comments from the editor. It's night, but this time, it's no dream: 
Yesterday evening I felt I must go out. A sudden thaw had set in, and I had heard that the river had overflowed, that all the brooks were swollen, and that from Wahlheim down, my beloved valley was flooded! I ran out after eleven at night. A terrible spectacle, to see the raging floods, descending from the rocks, swirling in the moonlight, cover fields and meadows and hedges and all, and the broad valley in both directions turned into a surging lake in the roar of the wind! And then when the moon came out again and rested above the dark cloud, and out in front of me the waters rolled and rang in the fearfully magnificent reflection: then a shiver came over me, and once more a longing! Ah, with open arms I stood facing an abyss, and murmured 'down! down!' and was lost in the rapture of having my torments, my suffering go sweeping down there! surging along with the waves! Oh!--and you were unable to life your feet from the ground and put an end to all torments![23]

This letter continues with the water imagery and Werther's passive stance, and it shows a suicidal moment postponed (note, again, the shifting voice from "I/me" to "you" at the moment of possible active self-destruction). Even in the suicidal tone, it utilizes “bliss" [Wonne]: "Won't this imprisoned soul some day be released for such bliss?" [the bliss of immersion in the flood] (70, emphasis mine). This letter also depicts the "real" rather than metaphorical dangers of nature as a raging flood; yet when Goethe moves it back into the post-rupture collection of notes and voices, its solidity, its finality, its very confirmation of Werther's every fear is relegated to a more subjective position. In both versions, however, this third nature letter stands as a final epistolary documentation of Werther's unchanging nature writing, a writing whose emotional trappings swing from one dualistic extreme to the other even while its structure, water imagery, choice of vocabulary, and passive position of the speaker remain the same. The rupture of Werther's nature views is artificial, and functions to distract from the more radical structural 
ruptures of monologue and body. There's even more to this contrast, however, as the joke's once again on us in that all of this furious passivity and these claims of unmediated immersion in nature occur in the decidedly active and fictional--epistolary--construction of self and world. The novel Werther is a monument to the juxtaposition of passive/active, mediated/unmediated views, of monologue and multiple voices, of erupting physical desire and calm, "outside" voices. The problem--or rather, the text's power--is that the sweeping landscapes of nature's delights and the breathtaking heights of inward dreams and passion all too often sway the reader into seeing consistency where there is jagged edge, and jagged edge where there is consistency.

Werther is usually believed to suffer from boundary loss, I see him instead as enacting boundary distortion. He is unable to contain rupture--it, in fact, replaces his voice and finally shatters his body. Repeatedly, Werther wails that he suffers from imprisoning limitations, and he seeks transcendence through sinking into nature's flow. These impulses are, again, two sides of the same boundary distortion whereby the desired fictional immersion serves only to accentuate (the itself fictional) separation rather than eliminate it. Werther is unable to capture the energy of rupture in any form, instead he is overwhelmed by it, he misreads it, he attempts to fall into it passively; until, that is, he finally embraces it with a violence that destroys him. His desire to live only within one side or the other are exactly that which Goethe strove to vanquish in both his scientific and literary undertakings, as we see in his 1793 essay, Experiment as Mediator of Object and Subject, a text that reads like a direct response to Werther:

As soon as man perceives objects around him, he considers them in relation to himself. Rightly so, as his entire fate depends on whether they please or displease him, attract or repulse him, are useful or harmful to him. This entirely natural manner to see things and to judge them appears to be as easy as it is necessary, and yet man thereby encounters a thousand mistakes that often shame him and make his life bitter.[24] 
The gist of this essay is that one should consider the objects in light of themselves and their relationships to other things and not just to one's own subjectivity; yet, simultaneously, Goethe notes that we must always remember our mediated responses--that we must always "be mistrustful regarding oneself." Perception is itself simultaneously receptive and productive; it is ideally, for Goethe, a making conscious of the rupture, an engaging of the polarity. This essay describes Goethe's theory of scientific undertaking, that which guides his every encounter with nature. One might say that Werther long precedes such scientific work, yet Goethe's interest in nature is life-long, as are his views that subject/object relationships are not simple dichotomies. In addition, shortly after 1774 , Goethe shifted his pursuit of nature towards ever more scientific views, to those ideas with which he felt he had accomplished far more in his life than his literary accomplishments. Werther the text marks for more reasons than one a juncture--one might say a rupture--in Goethe's own life.[25]

The thesis of Goethe's essay Experiment as Mediator appears quite applicable to Werther in several other ways as well: in order to overcome our "Einschränkung" or "limitations"--the same word repeatedly used in the novel--we must work and speak with others, not fall into soliloquy: "It is true here as in so many human undertakings that only the interest of numerous people focusing on one issue is capable of bringing something outstanding to the fore" ("Experiment" 28). Goethe also argues that "unmediated" experiments based on limited evidence and allowing the free reign of the imagination lead us dangerously astray, whereas experience of a "higher form" of knowledge derives from carefully "mediated" interactions with much repetition, the consideration of a broad range of evidence, and only when all the results are brought together in order, only then, the controlled use of both theories and imagination: "We saw above that those who attempt to connect unmediated an isolated fact with their power of thinking and judgment are those who first fall into error. In contrast we will find that those who accomplish the most are 
those who never cease to research and work through all sides and modifications of a single experiment, a single attempt, in all its possibilities" ("Experiment" 33). Goethe concludes with the comment that only after one has carried out extended repetitions and careful consideration of every angle in each experiment should one attempt to apply judgment and imagination to the results. The Sorrows of Young Werther is Goethe's model of the opposite sort of experiment, of a leap into "unmediated" interaction with nature and uncontrolled flight of imagination and judgment about its meaning. This quest for freedom and unbounded experience often sees only itself, and it certainly ignores the "interest of numerous people." Hence it stands in danger of creating its own limitations that function as a fiction of truth.[26] For this reason, Goethe has the epistolary pretense of unmediated, individual veracity in Werther succumb to openly mediated and edited narrative. Yet this shift should not leave us simply with the acceptance that reality is always "mediated" by perception, language, or text. That would be too simple; instead, Goethe's shift requires the maintained recognition that effort to engage in unmediated exchanges must exist alongside the recognition that mediation is inevitably a part of these exchanges. It is not an accepting of one side of the dualism for another, but rather a juxtaposition of both in a manner uncomfortable, jarring, and edgy--this edginess, I suggest, is the disturbing energy of the novel Werther.

Werther perishes when he is unable to come to terms with this edginess. Instead of working with juxtaposition, he suddenly shifts to the opposite side: from passive to all-too-active. Increasingly construing himself as a Christ-figure who longs to die as a "sacrifice for Lotte," Werther commits suicide. With one pistol shot, Werther abandons his fictionalized passivity in response to nature, and chooses to commit an act that is simultaneously self-asserting and selfannihilating. The switch to violence against oneself is finally as much a disaster as all of his earlier passive, pastoral impulses. Here, again, are the flip-sides of the same dualistic vision of 
nature. What Werther neither in nature revelry nor in nature horror, and neither in passive immersion of self nor in active self-annihilation, can achieve, the novel itself does. Typical of Goethe, the answer lies in the in-between, in the polarity of transitions, the very shift itself, not either of the two sides. The answer, it seems, is in the seams.[27] One must emphasize what Karl J. Fink describes as Goethe's "border experiences," and "search for the elusive sutures, the hidden borders, the key linkages, namely by the recognition of thresholds in nature, where the study of static forms yield[s] to a science of dynamics." [28] The transitions from passion to agony, immersion to suicide, delusions of unmediated textual connection to recognition of our inevitably mediated accounts, from wet dream to editorial interruption, epistolary to mixed styles--these "elusive sutures"--are the dynamic core of the text. Out of a text about death emerges a dynamics of life, an energy of border experiences. Werther's tragedy is, finally, the cathartic necessity of fulfilling the unrealized implication of nature narratives that insist on passive bliss; yet his death as rupture also allows the juxtapositions of narrative form, of nature, and of the body, to emerge all the more dramatically.

Goethe portrays Werther's body in its drawn-out collapse with gory detail after the suicidal shot, a scene that finally brings the ruptured body to the fore. His death is gruesome, it lasts twelve hours, and, once again, presents us with a rupture that goes on and on: "When the surgeon arrived, Werther was lying on the floor; his pulse beat, but his limbs were paralyzed. The bullet had entered the forehead over the right eye; his brains were protruding. He was bled in the arm; the blood came, he was still breathing" (87). The extended time frame of Werther's death after the pistol shot portrays both the extended rupture and the suffering. His staged suicide right before Christmas thus provides the text with the closing juxtapositions of Christ's birth (and later death) with Werther's death, and of Werther's ostentatious prose about suffering nature's horrors with his bloody, paralyzed body. All that is left of his voice so evocatively filling 
most of the text is "a terrible rattling noise" that continues until he finally expires. If Werther writes nature as active force and himself as passive yet with a voice, he now fulfills that destiny. While the rupturing of Werther's epistolary monomania leads to a multiplicity of voices and narrative form on three levels (the other figures in the story, the editor's view from "outside," and the lengthy citations from Ossian allowing the rupture to reach all the way out of the novel into another text), the rupturing of Werther's body serves a similar, yet reversed function. First, we find the briefly mentioned, unvoiced reactions of the other figures: "The old man [Lotte's father] and his sons followed the body to the grave. Albert couldn't bring himself to. There was concern for Charlotte's life" (87). Second, the editor here adds no further comments of his own despite his earlier expansive analysis of the possible causes for Werther's fatal decision; instead he closes the text merely with unusually short and raw sentences: "The body was carried by workmen. No clergyman attended" (87). The body in death here takes precedence over the editor's overt role. The multiple voices and the editorial thoughts are all replaced by the briefest third-person reporting of events. In fact, the editor prefaces this final, stylistically unique section by openly requesting: "Let me say nothing of Albert's distress or of Charlotte's grief" (87). We are reminded then, of the editor, but he becomes a removed, quieted, narrator. Third, we also learn that in Werther's room, "Emilia Galotti lay open on his desk"; yet we are provided with no citations (unlike with Ossian). It might seem that the ruptured monologue opened the vista for multiple voices whereas the ruptured body shuts it down; yet on the contrary, we actually have here a second rupture out of the novel into an entirely different text.

Indeed, the entire final section of the novel, one set off from the rest of the text by a paragraph space after Werther writes a final "farewell!" to Charlotte, enacts another rupture, or move into a text "outside" just like the move into Ossian. This time it is the move to emulate the detailed letter from Goethe's friend Kestner about Jerusalem's suicide that was part of Goethe's 
inspiration for writing Werther.[29] In fact, the altered tone at the end of the novel, the description of the death, the factual and brief language at the very end, and the reference to Emilia Galotti, all provide a very close rendition of Kestner's letter. While much has been made of this historical, biographical reference, I want to emphasize again the parallel moment to the Ossian text as part of the rupture out of Werther's voice: here, too, at the close of the text, we have an opening, an extended rupture, one that leads all the way into another text, another voice. We are left with this other voice, this other letter, one chronicling a "real" event. Of course, it is, like Ossian not a simple, pure voice here as the text simulates the letter even while selectively highlighting and ignoring some details. The rupture of Werther's voice and body allows another voice beyond the protagonist's, the editor's, and even the author's, to be the final reverberation of the text--even while erasing the sense of "purity" that the voice might claim. All of the voices become multilayered. While the move into Ossian incites the body to a passionate kiss, the move into Kestner's letter ruptures the body in death and brings an open-ended step into other voices. There is finally no return. In Werther, the issues of voice and body, and so mediation and representation, collide in the intensity of the rupture. They are not resolved, rather they find a place of juxtaposition where the energized polarity remains open.[30] This insistence on ongoing movement is characteristic of all of Goethe's views of "nature," whether through poetic or scientific lens. As he writes in Towards a Theory of Color: "To divide the united, to unite the divided, is the life of nature; this is the eternal systole and diastole, the eternal collapsing and expansion, the inspiration and expiration of the world in which we live and move." [31]

What does this mean for Werther's nature writing? Simply this: while the novel annihilates the passive celebration of nature's aesthetic glory as fictionalized immediacy, it also denies voice to the pretense that bold action and self-assertion (violence as the extreme of active, and irony as simple antidote to pastoral celebration) is a reliable second option. In fact, I would 
say that Goethe's Werther belies the idea that we are either simply passive or active, simply

celebratory or skeptical, whether it be in terms of writing nature or existing inextricably as a part of nature. Instead, our writing, our speaking, our living, our walking (on the ants), our reading, our eating and breathing, all of it together, is simultaneously passive reception and active creation, both mediated and unmediated; and it is this juxtaposition that Werther the figure cannot accept. He wants it one way or the other. It's only in the ruptures (painful though they are), in the border experiences, in the transitions between seemingly unmediated and mediated experience, between our passive reception and active production, between, if you will, the epistolary monologue and the self-conscious narrative with multiple perspectives, that we can become aware of our entwined relationship with nature as world, as itself a give-and-take, an inhalation and exhalation. Nature is not just a text we create in epistolary dreams nor does it simply write us as we observe from a fantasy position of immersion by the babbling stream. Goethe disrupts, nay, annihilates, both positions in Werther. We are left, then, with Werther's ruptured monologue and ruptured body, and it is at this uncomfortably jagged place of disturbing energy where we too might begin our literary (and environmental) quest for "nature."

notes

1. The vast scholarship on Goethe's Werther demonstrates its significance as the first German text to gain world-wide attention, and its status as possibly the first "best seller" cult text. Briefly, major issues in the criticism include: the biographical relevance for Goethe regarding his claims to have considered suicide, his own love for two "Lottes," and the fact that he wrote Werther after receiving a detailed letter from Johann Kestner about their friend's, Carl Wilhelm Jerusalem's, actual suicide; the development and "writing" of modern, bourgeois subjectivity; Werther's sentimentality and pietistic self-examination, the novel as a high point and perhaps endpoint of the European epistolary novel; his pantheism and self-understanding as a Christ-figure; and the question of how self, nature, and society interact with fatal results.

2. Other critics have also emphasized various "ruptures" in Werther; see, in particular: Benjamin Bennett, Raymond Prier, Joyce Walker, and Davide E. Wellbery. More traditional readings view Werther as a contrast between the "ideal" and "real"; see, for example, Hartmut Vollmer. 
3. Hans Peter Herrmann's collection of essays from 1876 to 1992 on Werther illuminates the novel's continuing influence, provides much of the biographical information, and describes the "Werther-fever" that followed Goethe throughout his life. For a discussion in English of Werther as a "fashion," and detailed insight into Goethe's life, see Nicholas Boyle's biography.

4. In writing this essay with English translations, I encountered a number of unexpected problems. First, the translations I found (from Suhrkamp, Continuum, Signet, Knopf, and others) failed to note specific aspects of the German essential for this analysis. Most references here are to the Suhrkamp edition edited by Wellbery and translated by Victor Lange, henceforth listed parenthetically in the text. When this edition translates key passages without recognition of issues central to my analysis, however, (like Werther's consistent switch from "I" to "you" when considering a shift from passive to active stance), I use instead Continuum's "The German Library" translation from Bayard Quincy Morgan, edited by Victor Lange. In order to avoid confusion, these passages from the Continuum translation shall be noted in the endnotes. Several translations are also my own; these are from the Klassiker edition, Frankfurt. In addition, all the English translations that I found were from the famous revision to Werther made in 1787. As I discuss here the differences between the two versions, all translations from the first, 1774, edition are my own. Finally, some of the English editions problematically eliminate the first comments from the editor altogether.

5. Examples of the three groups of Werther interpretations include: sentimental: Dirk Grathoff, Hans-Heinrich Reuter, and Boyle who sees the editor as an extension of Werther; critical and ironic: Victor Lange, Alan C. Leidner, and Prier; and, juxtaposition or the tension between the two sides: Astrida Tantillo's "A New Reading," which emphasizes "a specific tension between the surface of the text and its embedded content. In other words, Goethe's Werther contained from its inception a kind of self-reflection that opens the text to at least two concurrent and contradictory interpretations: a sympathetic one that identifies with Werther and a critical one that distances the reader from him" (444). Bruce Duncan also stresses both sides: "Werther is constructed of ironic devices that on the one hand assert the power of its hero's inner life and on the other set a question mark behind it" ("Werther" 1); see also his "Emilia Galotti," and Erdmann Waniek's essay on Werther as "Reader" and "Reading Werther."

6. Much has been made of Werther's self-declared narrative struggles; see, for example, Martin Swales who describes Werther's two narrative styles "of recounting events in their chronological sequence" and "of reflection, commentary, discursive analysis" (62). Chenxi Tang sees Werther's suicide itself "an ultimate act of writing intended to terminate all further acts of writing which might beset nature" (110). See also Bennett.

7. There is actually another level of complexity here: the editor (or author) includes the occasional footnote speaking directly to the reader regarding the suppression of names and places so as "not to offend anyone." These could be read as supporting the idea of historical veracity, or as small interruptions from the editor.

8. For examples of these discussions about the identity of the editor, see: Erick A. Blackall, who describes the final section as entirely "colored by Werther's own viewpoint," thus as the "ghost" of Werther; Christoph E. Schweitzer's "Who Is the Editor of Goethe's Werther?"; and Boyle. 
9. For examples of comparisons to Romanticism, see Stuart Walker Strickland and Steven P. Sondrup. Other critics emphasize various kinds of transitions or ruptures in the text, yet still ignore the editor: see, for example, Walker and Wellbery.

10. There is little agreement in the criticism about this lengthy passage. Some see it simply as another autobiographical touch where Goethe includes his meticulous translation. Regarding its length, Bennett asks: "The question is: are three wheelbarrows of text needed to do the job, or would two and a half accord better with the reader's sense of emotional time?" (115). I disagree, however, with Bennett's statement that at the climax of the text, "we find ourselves looking at a text that does not need to be there" (115).

11. Duncan calls this series of voices "ironic Chinese boxes"; noting that "Ossian has learned these songs from earlier singers, who had themselves picked them up from other sources" (“Emilia Galotti” 45).

\section{See Prier's discussion.}

13. The discussion of Werther's readings, Werther as (mis-)reader, and Goethe/Werther and their literary tastes is vast; exemplary discussions include: Duncan's “Emilia Galotti," Tantillo's "A New Reading," Waniek, and many of the essays in Herrmann's collection.

14. Edgar Landgraf considers Werther as a prime example of the paradox of "mediated immediacy" but in terms of love and writing: "Werther acknowledges the paradoxical situation that confronts any attempt to communicate love in its authenticity and immediacy and puts this problem at the center of its love experience, as well as its reflections on art and poetry. In fact, it is precisely because art and literature are asked to communicate the incommunicable that literature can become the primary medium for both the expression and experience of love. For that reason, Werther can experience his love only as suffering, as an inherent impossibility, something that eludes realization because it is only possible as a literary or artistic act" (7).

15. Polarity is one of the most famous concepts in Goethe's science and literature. See, in particular, Tantillo's discussion in The Will to Create, chapter 2.

16. There are many sources discussing Goethe's changes to the novel, yet Deirdre Vincent's book definitely stands out with its detail, attention to Goethe's life during his revision and his love for the second Lotte, Charlotte von Stein. Many critics instead see the later text simply as a refinement and additional comments on his love for the first Lotte.

17. My translation, Klassiker 198.

18. This is from the Continuum translation, 94. The Suhrkamp translation neglects the predominant water imagery, and understands the "fremde Mächte" as "supernatural power" rather than the more fitting "alien powers."

19. Herrmann concentrates his analysis in "Landschaft" on the first two of these letters in an exceptional reading of nature in Werther, but one that leads primarily to a "dialectic of heart" as a social critique without the parallel dialectic of the body and comparison to the third letter.

20. See Herrmann's "Landschaft" for a similar discussion of the juxtaposition of passive self and active nature. Sondrud and others also note Werther's passivity in reference to nature. 
21. This is from the Continuum translation which notes the "I/you" switch, (17, emphasis mine).

22. Translation mine; neither Suhrkamp nor Continuum includes the threefold "I/you" switch.

23. Continuum translation, 93-94, emphasis mine.

24. Translation mine, from Klassiker, Der Versuch als Vermittler von Objekt und Subjekt 26.

25. See E.L. Stahl on Werther as a transition for Goethe.

26. Thus this essay "Experiment as Mediator" dedicates several pages to the critique of theories that reflect individual egos rather than nature. Goethe proposes accepting the anthropocentric coloring of world that is our view even while encouraging nature to emerge on its own terms by performing many repeated experiments before making theories. It is, again, a view that rejects the pretense that we can function entirely from only one side or the other.

27. As Duncan puts it: “Or, to return to Goethe's simile of the torn cloth, the novel's art is to be found not in the whole garment, but in the stitching that both mends and reveals the rent in the fabric" ("Werther" 8).

28. Karl J. Fink 50.

29. I would again disagree here with Bennett, who states that: "The extent to which Goethe reproduces the circumstances of Jerusalem's actual suicide is of no special significance here" (53). First, it is the reference to the letter itself as text--which Goethe practically quotes verbatim--rather than "the circumstances"; and second, this reference, as a move into another text, mirrors the earlier move into the Ossian text (whose significance Bennett also disregards).

30. Prier also notes: "His juxtaposition of imploding and cultivating worlds creates narrative conflicts within the novel that continually cry in vain for resolution" (296).

31. English translation of Goethe's Color Theory, Editor Rupprecht Matthaei, \#739; (164). Goethe considered this work on optics to be his greatest lifelong achievement, far more significant than his literary efforts that made him so famous.

references

Bennett, Benjamin. Goethe as Woman: The Undoing of Literature. Detroit: Wayne State UP, 2001.

Blackall , Eric A. Goethe and the Novel. Ithaca: Cornell UP, 1976.

Boyle, Nicholas. Goethe: The Poet and The Age. Vol. I. Oxford: Oxford UP, 1991.

Duncan, Bruce. "'Emilia Galotti lag auf dem Pult aufgeschlagen': Werther as (Mis-)Reader." Goethe Yearbook 1 (1982): 42-50.

---. "Werther's Reflections on the Tenth of May." Exile and Enlightenment: Studies in German and Comparative Literature. Eds. Uwe Faulhaber, et al. Detroit: Wayne State UP, 1987. 1-9.

Fink, Karl J. Goethe's history of science. Cambridge: Cambridge UP, 1991. 
Goethe, Johann W. "Experiment as Mediator of Object and Subject. ["Der Versuch als Vermittler von Objekt und Subjekt." Sämtliche Werke v. 25: Schriften zur Allgemeinen Naturlehre, Geologie und Mineralogie. Frankfurt am Main: Klassiker, 1989. 26-36.

---.Goethe's Color Theory. Ed. Rupprecht Matthaei. New York: Van Nostrand Reinhold, 1971.

---. The Sorrows of Young Werther. Ed. David E. Wellbery. Trans. Victor Lange. New York:

Suhrkamp, 1998. [Source most often referenced here.]

---. The Sufferings of Young Werther. Ed. Victor Lange. Trans. Bayard Quincy Morgan. New York: Continuum, 1991.

Grathoff, Dirk. "Der Pflug, die Nussbäume und der Bauerbursche: Natur im thematischen Gefüge des 'Werther'-Romans." Goethes "Werther": Kritik und Forschung. Ed. Hans Peter Hermann. Darmstadt: Wissenschaftliche Buchgesellschaft, 1994. 382-402.

Herrmann, Hans Peter, ed. Goethes "Werther": Kritik und Forschung. Darmstadt: Wissenschaftliche Buchgesellschaft, 1994.

---. "Landschaft in Goethes 'Werther': Zum Brief vom 18. August." Goethes "Werther": Kritik und Forschung. Ed. Hans Peter Hermann. Darmstadt: Wissenschaftliche Buchgesellschaft, 1994. 360381.

Landgraf, Edgar. "Romantic Love and the Enlightenment: From Gallantry and Seduction to Authenticity and Self-Validation." German Quarterly 77.1 (2004): 29-47.

Lange, Victor. "Die Sprache als Erzählform in Goethes 'Werther.'“ Goethes "Werther": Kritik und Forschung. Ed. Hans Peter Hermann. Darmstadt: Wissenschaftliche Buchgesellschaft, 1994. 193206.

Leidner, Alan C. The Impatient Muse: Germany and the Sturm und Drang. Chapel Hill: U of North Carolina P, 1994.

Prier, Raymond A. "Charlotte's Vicar and Goethe's Eighteenth-Century Tale about Werther." Narrative Ironies. Eds. A. Prier and Gerald Gillespie. Amsterdam: Rodopi, 1997. 283-297.

Reuter, Hans-Heinrich. "'Die Leiden des jungen Werthers.'“ Goethes "Werther": Kritik und Forschung. Ed. Hans Peter Hermann. Darmstadt: Wissenschaftliche Buchgesellschaft, 1994. 248265.

Schweitzer, Christoph. "Who Is the Editor in Goethe's Die Leiden des jungen Werthers?" Goethe Yearbook 12 (2004): 31-40.

Sondrup, Steven P. "Wertherism and Die Leiden des jungen Werther. European Romanticism: Literary Cross-Currents, Modes and Models. Ed. Gerhart Hoffmeister. Detroit: Wayne State UP, 1990. 163179.

Stahl, E.L. Ed. Die Leiden des jungen Werthers. Oxford: Blackwell, 1992.

Strickland, Stuart Walker. "Flight from the Given World and Return to the New: The Dialectic of Creation and Escape in Goethe's Die Leiden des jungen Werther." The German Quarterly 64.2 (1991): 190-206.

Swales, Martin. Goethe: The Sorrows of Young Werther. Cambridge: Cambridge UP, 1987.

Tang, Chenxi. "Two German Deaths: Nature, Body and Text in Goethe's Werther and Theodor Storm's Der Schimmelreiter." Orbis Litterarum 53 (1998): 105-116. 
Tantillo, Astrida. "A New Reading of Werther as Goethe's Critique of Rousseau." Orbis Litterarum 56 (2001): 443-465.

---. The Will to Create: Goethe's Philosophy of Nature. Pittsburgh: U of Pittsburgh P, 2002.

Vincent, Deirdre. Werther's Goethe and the Game of Literary Creativity. Toronto: U of Toronto P, 1992.

Vollmer, Hartmut. "“Worte sind hier umsonst': Die Beschreibung des Unbeschreiblichen in Goethes Werther und Hölderlins Hyperion." Zeitschrift für deutsche Philologie 122 (2003): 481-508.

Walker, Joyce. "Sex, Suicide, and the Sublime: A Reading of Goethe's Werther." Monatshefte 91.2 (1999): 208-224.

Waniek, Erdmann. “Werther Lesen und Werther als Leser.” Goethe Yearbook 1 (1982): 51-92.

Wellbery, David E. “Morphisms of the Phantasmatic Body: Goethe's The Sorrows of Young Werther." Body and Text in the Eighteenth Century. Eds. Veronica Kelly and Dorothea von Mücke. Stanford: Stanford UP, 1994. 